\title{
Microbial community analysis for aerobic granular sludge reactor treating high-level 4-chloroaniline wastewater
}

\author{
L. Zhu $\cdot$ X. Dai $\cdot$ X. Xu $\cdot$ M. Lv $\cdot$ D. Cao
}

Received: 16 January 2013/Revised: 21 June 2013/Accepted: 9 September 2013/Published online: 30 October 2013

(C) Islamic Azad University (IAU) 2013

\begin{abstract}
A laboratory-scale sequencing airlift bioreactor continuously treating high-level 4-chloroaniline (4-ClA) wastewater was used for studying the effect of 4-ClA on the characteristics and microbial community of aerobic granular sludge. The granulation of aerobic sludge and efficient pollutant removal performance were developed via shortening sludge settling time and gradually increasing influent 4-ClA concentration to around $400 \mathrm{mg} \mathrm{L}^{-1}$. However, the granular sludge reactor deteriorated with the 4-ClA loading rate above $0.8 \mathrm{~kg} \mathrm{~m}^{-3} \mathrm{~d}^{-1}$. Denaturing gradient gel electrophoresis and real-time quantitative PCR were applied to investigate the microbial community succession during the start-up and recovery of bioreactor. The results showed that the performance of granular reactor was significantly influenced by the microbial community of aerobic granule, and stable aerobic granule was dominated with $\beta$-Proteobacteria (61.28 \%), Flavobacteriales, Planctomycetales, Clostridiales, and Acidobacteria. Since Thauera $(21.55 \%)$ related to the genus $\beta$-Proteobacteria was abundant in the stable 4-ClA-degrading granular sludge, it was speculated as the main 4-ClA-degrading bacteria. Under high chloroaniline level, the sludge granulation may maintain the stability of the bioreactor via adjusting the composition of microbial community and abundance of functional microorganism. This paper provided useful information for better understanding the change of microbial community characteristics under highlevel toxic organic pollutants and process optimizing.
\end{abstract}

L. Zhu $(\bowtie) \cdot$ X. Dai $\cdot$ X. Xu $\cdot$ M. Lv $\cdot$ D. Cao

Department of Environmental Engineering, Zhejiang University, Hangzhou 310058, China

e-mail: felix79cn@hotmail.com
Keywords Aerobic granular sludge $\cdot$ 4-Chloroaniline (4ClA) $\cdot$ Microbial community $\cdot$ Succession $\cdot$ Thauera sp.

\section{Introduction}

Chloroaniline is a class of carcinogenic, mutagenic, and teratogenic persistent organic pollutants that has been used widely in the dye, pesticide, pharmaceutical, and preservative production in the world and threaten the ecosystem safety and human health. Therefore, many biological treatment processes have been established to improve their removal efficiency, such as anaerobic granular sludge technology, biofilm reactor, and immobilized microorganism technology (Boon et al. (2003) and Bathe et al. (2009)). For example, Boon et al. (2003) reported that addition of the Comamonas testosteroni $\mathrm{I} 2$ strain isolated from an activated sludge reactor could enhance the 3-ClA degradation. However, loss of the functional bacteria occurred, and the performance of the reactor finally deteriorated (Boon et al. 2002). It is clear that enriching and maintaining functional microorganisms are important for the efficient treatment of toxic organic wastewater (Zhang et al. 2011).

Aerobic granules are self-immobilized and mixed-culture microbial aggregates and have excellent potential for the application in the areas of dewatering improvement, residual sludge minimization, simultaneous biological nitrogen and phosphorus removal, and toxic organic compound degradation. Since Morgenroth et al. (1997) found the aerobic sludge granulation in a sequence bioreactor, researchers have conducted numerous studies on the formation and characteristics of aerobic granule, affecting factors of sludge granulation, mass transfer and model simulation, extracellular polymeric substances (EPS), and 
formation mechanism (Beun et al. 2002; Liu et al. 2006; Wan et al. 2009; de Kreuk et al. 2010; Ni and Yu 2010; Gao et al. 2011, Uan et al. 2013). However, the aerobic granular sludge system is still not stable, and the application of this technology is faced with big bottlenecks and challenges (Winkler et al. 2011; Chen et al. 2007; Adav et al. 2008; Liu and Tay 2008).

It is well known that the microbial communities of activated sludge and biofilms affect the performance of biological wastewater treatment systems, and molecular biology techniques, such as PCR, denaturing gradient gel electrophoresis (DGGE) and fluorescence in situ hybridization (FISH), have been extensively applied in the related fields (Muyzer et al. 1993; Deng et al. 2012). Boon et al. (2003) compared the microbial communities of activated sludge from fourteen Belgian sewage treatment plants using PCR-DGGE analysis and found that the plants were dominated with $\beta$-Proteobacteria and Acidobacterium, and the community diversity was associated with the value of sludge volume index (SVI). Liu et al. (2006) characterized the enhanced biological phosphorus removal systems using FISH and showed that the efficient phosphorus removal performance was associated with the enrichment of Candidatus Accumulibacter phosphatis. Deng et al. (2012) demonstrated that under high antibiotic level, the wastewater treatment system was stability through adjusting the bacterial, archaeal, and eukaryal compositions.

Our previous studies showed that aerobic 4-ClAdegrading granules could be cultivated under the condition of high chloroaniline loading rates (Zhu et al. 2008, 2011). In this study, the impacts of high-level 4-ClA on wastewater treatment communities are revealed via investigating the succession of microbial community in aerobic granular sludge reactor, and the community structures during the start-up and recovery stages of bioreactor are characterized using PCR-DGGE and realtime quantitative PCR. The purpose of this study is to provide useful information for understanding the characteristics of microbial community under high-level toxic organic pollutants and process optimizing.

\section{Materials and methods}

Experimental setup and sludge sample

A 5-L sequencing airlift bioreactor (SABR) used in this study $(8 \mathrm{~cm}$ of down-comer I.D., $64 \mathrm{~cm}$ of riser height, and $5 \mathrm{~cm}$ of riser I.D.) was established in a temperaturecontrolled room at $25 \pm 2{ }^{\circ} \mathrm{C}$ and operated in 12-h cycle consisting of $20 \mathrm{~min}$ of influent filling, 685-690 min of aeration, 5-10 min of settling, and $5 \mathrm{~min}$ of effluent withdrawal. For the aeration, fine air bubbles were supplied through a dispenser at the reactor bottom at a superficial gas velocity of $2.4 \mathrm{~cm} \mathrm{~s}^{-1}$. Effluent was discharged at a volumetric exchange ratio of $70 \%$, equivalent to a hydraulic retention time of $17.2 \mathrm{~h}$. The abiotic loss of 4-ClA in the SABR was negligible under identical operational conditions.

Inoculated sludge consisted of activated sludge from the aeration tank of the Sibao Wastewater Treatment Plant in Hangzhou, which was dark yellow or brown in color and flocculent in shape with a mixed liquor suspended solid (MLSS) value of approximately $2.15 \mathrm{~g} \mathrm{~L}^{-1}$ and an SVI of approximately $120 \mathrm{~mL} \mathrm{~g}^{-1}$. The compositions of synthetic wastewater and trace mineral solution were analyzed according to the method reported by Zhu et al. (2011). The experimental parameters were adjusted based on the operational conditions of the reactor, as shown in Table 1.

The target of pollutant of the aerobic granular sludge bioreactor was 4-ClA. The influent substrates contained readily biodegradable organics, such as glucose and acetate. The $\mathrm{COD} / \mathrm{N} / \mathrm{P}$ ratio was maintained constantly at 100:5:1.
Table 1 Operational conditions of aerobic granular sludge reactor

\begin{tabular}{|c|c|c|c|}
\hline \multirow[t]{2}{*}{ Operational parameter } & \multicolumn{3}{|l|}{ Stage } \\
\hline & I ( $1-15$ days $)$ & II (16-90 days) & III (91-150 days) \\
\hline Cycle time (h) & 12 & 12 & 12 \\
\hline Influent (min) & 20 & 20 & 20 \\
\hline Aeration (min) & 685 & 690 & 690 \\
\hline Settling (min) & 10 & 5 & 5 \\
\hline Effluent withdrawal (min) & 5 & 5 & 5 \\
\hline Influent COD $\left(\mathrm{mg} \mathrm{L}^{-1}\right)$ & $500-1,200$ & $1,000-1,800$ & $700-1,800$ \\
\hline Influent 4-ClA (mg L $\left.{ }^{-1}\right)$ & $0-10$ & $10-450$ & $180-400$ \\
\hline Superficial air velocity $\left(\mathrm{cm} \mathrm{s}^{-1}\right)$ & 2.4 & 2.4 & 2.4 \\
\hline
\end{tabular}


Analysis methods

\section{Conventional chemical analysis}

Raw samples from the SABR were periodically analyzed for COD, pH, MLSS and volatile suspended solids (VSSs), and SVI in accordance with standard methods in APHA (1998). 4-ClA was analyzed using HPLC, and the analytical method is detailed in Zhu et al. (2011). All samples were analyzed in triplicate.

\section{DNA extraction and determination}

The extraction and purification of total DNA from sludge samples were performed using the 3S DNA isolation kit for environmental samples V2.2 from Biocolor BioScience and Technology (Shanghai). The integrity of the extracted DNA was determined using $1 \%$ agarose gel electrophoresis. The DNA concentration was determined in triplicate using a SHIMADZU 2401PC UV spectrophotometer and then was stored at $-20{ }^{\circ} \mathrm{C}$.

PCR amplification and DGGE PCR amplification was performed on an iCycle thermal cycler (Bio-Rad). The bacterial 16S rRNA V3 variable regions were amplified by PCR using the following universal bacterial primers: GCPRBA338f and PRUN518r synthesized by TaKaRa (Dalian, China). The PCR was carried out in a total volume of $50 \mu \mathrm{L}$ containing: $5 \mu \mathrm{L}$ of $10 \times$ PCR buffer $(15 \mathrm{mM}$ $\left.\mathrm{Mg}^{2+}\right), 4 \mu \mathrm{L}$ of dNTP mixture (2.5 mM each), $1 \mu \mathrm{L}$ each of primers $(25 \mu \mathrm{M}), 0.5 \mu \mathrm{L}$ of Taq DNA polymerase, approximately $15 \mathrm{ng}$ of DNA template, and DEPC-treated water (RNase-free). The cycling parameters were as follows: one cycle of denaturation at $94{ }^{\circ} \mathrm{C}$ for $10 \mathrm{~min}$, 30 cycles of denaturation at $94{ }^{\circ} \mathrm{C}$ for $30 \mathrm{~s}$, annealing at $55{ }^{\circ} \mathrm{C}$ for $30 \mathrm{~s}$, and extension at $72{ }^{\circ} \mathrm{C}$ for $60 \mathrm{~s}$, followed by a final extension at $72{ }^{\circ} \mathrm{C}$ for $7 \mathrm{~min}$. PCR amplification products were stored at $-20{ }^{\circ} \mathrm{C}$ after confirmation by $1.5 \%$ agarose gel electrophoresis.

Denaturing gradient gel electrophoresis analysis for PCR products was performed on a Bio-Rad DCode System according to the following procedure: $8 \%$ polyacrylamide gel (acrylamide/bis-acrylamide 37.5:1) was mixed with $80 \mu \mathrm{L}$ of $10 \%$ ammonium persulfate and $18 \mu \mathrm{L}$ of TEMED, and the denaturing gradient range was set at 30-60\% (100\% denaturing agents contained $7 \mathrm{M}$ urea and $40 \%$ deionized formamide). The samples were loaded onto the gel with $50-\mu \mathrm{L}$ micropipette, and the gel was prerun at $20-40 \mathrm{~V}$ for $30 \mathrm{~min}$ followed by $150-160 \mathrm{~V}$ at $60{ }^{\circ} \mathrm{C}$ for $5-6 \mathrm{~h}$ in $1 \times$ TAE buffer $(40 \mathrm{mM}$ Tris base, $20 \mathrm{mM}$ glacial acetic acid, $1 \mathrm{mM} \mathrm{Na}_{2}$ EDTA). After electrophoresis, the gel was stained with Goldviewna II, purchased from BioDev-Tech (Beijing, China), for $20 \mathrm{~min}$ in the dark and then was subsequently washed with $\mathrm{dH}_{2} \mathrm{O}$ for $5 \mathrm{~min}$. The DGGE gel image was collected using the GelDoc2000 gel imaging system (Bio$\mathrm{Rad}$ ), and the fingerprint was analyzed using Quantity One 1-D Analysis Software v4.5 (Bio-Rad).

\section{DNA cloning and sequence analysis}

The target bands on DGGE gel were carefully excised with a sterile scalpel, transferred to sterile centrifuge tubes, and washed with sterile water three times. Gels were then cut into small pieces and put in $50 \mu \mathrm{L}$ of $\mathrm{TE}(\mathrm{pH} 8)$, and gel slices were incubated at $4{ }^{\circ} \mathrm{C}$ for $16 \mathrm{~h}$. After incubation at $37{ }^{\circ} \mathrm{C}$ for $2 \mathrm{~h}$, the samples were placed at $4{ }^{\circ} \mathrm{C}$ for $30 \mathrm{~min}$. The supernatant was collected after centrifugation at $10,000 \mathrm{rpm}$ for $1 \mathrm{~min}$, and the recovered DNA was used as a template for the PCR amplification with the primers PRBA338f and PRUN518r. The PCR conditions refer to the above.

Cloning and sequencing were performed by Invitrogen (Shanghai) as follows: The PCR product was recovered using a gel extraction kit, and the size of the product was confirmed by agarose gel electrophoresis of $5 \mu \mathrm{L}$ of the recovered DNA product; the purified product was ligated into the pMD18-T vector and transformed into Escherichia coli strain DH5 $\alpha$; positive colonies were selected using blue/white screening and inoculated into culture medium; plasmids were extracted using a plasmid purification kit and identified by PCR with the M13F(-47) and M13R(-48) primers; the plasmids were further confirmed by EcoRI and SalI double digestion; and the identified samples were sequenced. The obtained sequences were compared with nucleotide sequences in GenBank using the BLAST program (http://www.ncbi. nlm.nih.gov/blast/). Related strains highly homologous to the obtained clones were selected for the construction of a phylogenetic tree. The sequences acquired from GenBank and the sequences obtained in this study were input into DNAStar, and the maximum parsimony method was used to construct a phylogenetic tree. The comparison of some 16S rRNA sequences in the GenBank database (NCBI) was performed using ClustalW v1.8 for sequence comparison and genetic analysis, and the neighbor-joining method in DNAStar was used for the construction of a phylogenetic tree (Neighbor-Joining/UPGMA, version 3.6).

\section{$P C R$ and quantitative real-time PCR}

Four pairs of primers were designed for the detection of total bacteria, $\beta$-Proteobacteria, Thauera $\mathrm{sp}$, and ammonia-oxidizing bacteria (AOB). Amplification was performed with the SYBR Green fluorescence quantitation kit 
Table 2 RTQ-PCR primer and operational parameters

\begin{tabular}{|c|c|c|c|}
\hline Species & Primer & Sequence & Operational parameters \\
\hline \multirow[t]{2}{*}{ Eubacterium } & P338f & $\begin{array}{l}5^{\prime}-\mathrm{ACT} \text { CCT ACG GGA GGC } \\
\text { AG-3' }\end{array}$ & $\begin{array}{l}94{ }^{\circ} \mathrm{C} 5 \mathrm{~min} ; 94{ }^{\circ} \mathrm{C} 30 \mathrm{~s}, 55^{\circ} \mathrm{C} 30 \mathrm{~s} \text {, } \\
72{ }^{\circ} \mathrm{C} 60 \mathrm{~s}, 35 \text { cycles }\end{array}$ \\
\hline & P518r & $\begin{array}{l}\text { 5'-ATT ACC GCG GCT GCT } \\
\text { G-3' }\end{array}$ & \\
\hline \multirow[t]{2}{*}{${ }^{\beta-}$ Proteobacteria } & $\begin{array}{l}27 f- \\
\text { GC }\end{array}$ & $\begin{array}{l}\text { 5'-GAG AGT TTG ATC CTG } \\
\text { GCT CAG-3' }\end{array}$ & $\begin{array}{l}94{ }^{\circ} \mathrm{C} 5 \mathrm{~min} ; 94{ }^{\circ} \mathrm{C} 30 \mathrm{~s}, 55^{\circ} \mathrm{C} 30 \mathrm{~s}, \\
72{ }^{\circ} \mathrm{C} 60 \mathrm{~s}, 35 \text { cycles }\end{array}$ \\
\hline & bP365r & $\begin{array}{l}\text { 5'-GCG CCC ATT GTC CAA } \\
\text { A-3' }\end{array}$ & \\
\hline \multirow[t]{2}{*}{ Thauera sp. } & - & $\begin{array}{l}\text { 5'-GAG AGT TTG ATC CTG } \\
\text { GCT CAG-3' }\end{array}$ & $\begin{array}{l}94{ }^{\circ} \mathrm{C} 5 \mathrm{~min} ; 94{ }^{\circ} \mathrm{C} 30 \mathrm{~s}, 57^{\circ} \mathrm{C} 30 \mathrm{~s} \text {, } \\
72{ }^{\circ} \mathrm{C} 60 \mathrm{~s}, 35 \text { cycles }\end{array}$ \\
\hline & & $\begin{array}{l}\text { 5'-CTA CGG CTA CCT TGT } \\
\text { TAC GA-3' }\end{array}$ & \\
\hline \multirow[t]{2}{*}{ AOB } & P189f & 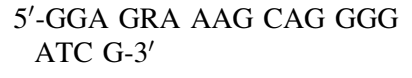 & $\begin{array}{l}94{ }^{\circ} \mathrm{C} 5 \mathrm{~min} ; 94{ }^{\circ} \mathrm{C} 30 \mathrm{~s}, 57^{\circ} \mathrm{C} 30 \mathrm{~s} \text {, } \\
72{ }^{\circ} \mathrm{C} 60 \mathrm{~s}, 35 \text { cycles }\end{array}$ \\
\hline & $\mathrm{P} 654 \mathrm{r}$ & $\begin{array}{l}\text { 5'-CTA GCT TTG TAG TTT } \\
\text { CAA ACG C- } 3^{\prime}\end{array}$ & \\
\hline
\end{tabular}

Table 3 Relevant parameters of RTQ-PCR standard curve

\begin{tabular}{llll}
\hline Species & $\mathrm{R}^{2}$ & Standard curve & $\begin{array}{l}\text { Solute peak } \\
\left({ }^{\circ} \mathrm{C}\right)\end{array}$ \\
\hline Eubacterium & 0.997 & $\begin{array}{c}\mathrm{Ct}=-4.233 \\
\operatorname{lgC}+37.632\end{array}$ \\
B-Proteobacteria & 0.985 & $\begin{array}{c}\mathrm{Ct}=-3.926 \\
\operatorname{lgC}+32.108\end{array}$ \\
Thauera sp. & $0.994 \quad \begin{array}{c}\mathrm{Ct}=-3.265 \\
\operatorname{lgC}+18.694 \\
\mathrm{Ct}=-3.379 \\
\operatorname{lgC}+25.579\end{array}$ & 81.3 \\
AOB & 0.983 & 82.4 \\
\hline
\end{tabular}

on a Bio-Rad IQ5 quantitative PCR machine (PCR was performed to determine the optimal conditions and parameters for each sample, shown in Table 2).

The 16S rRNA genes from total bacteria, $\beta$-Proteobacteria, Thauera sp., and AOB cloned into pMD18-T served as quantitative standards. Positive control recombinant plasmids were prepared using the TA cloning method. After enzymatic digestion, plasmids were confirmed by agarose gel electrophoresis and sequencing, and the corresponding fragments were quantitated to calculate the copy number per unit volume. Standards were serially diluted tenfold, and $0.5 \mu \mathrm{L}$ was used as a template for quantitative PCR to generate standard curves. The recombinant plasmids were diluted and quantitated, and the dilutions that were closest to the following values were selected: $1 \times 10^{5}, 1 \times 10^{6}, 1 \times 10^{7}, 1 \times 10^{8}$, and $1 \times 10^{9}$ copies $\mathrm{mL}^{-1}$. Standard curves for each species of bacteria were obtained using the RT-qPCR results from a standard with a known starting copy number. Results are shown in Table 3.
The extracted genomic DNAs from environmental samples were used for RT-qPCR amplification with the four pairs of primers using the method described above, and four $\mathrm{C}_{\mathrm{t}}$ values were obtained. Total copy numbers of $16 \mathrm{~S}$ rRNA in total bacteria, $\beta$-Proteobacteria, AOB, and Thauera sp. were confirmed according to the standard curve. Because the copy number of $16 \mathrm{~S}$ rRNA varies between different species of bacteria, the average $16 \mathrm{~S}$ rRNA copy numbers of total bacteria, $\beta$-Proteobacteria, Thauera sp., and AOB, according to the data provided by http://rrndb.cme.msu.edu, were used as conversion factors to calculate the percentage composition of the four species in the original samples. All samples were analyzed in triplicate.

\section{Results and discussion}

Performance of aerobic granular sludge reactor

The bioreactor was started up with a 4-ClA loading rate of $20 \mathrm{~g} \mathrm{~m}^{-3} \mathrm{~d}^{-1}$ and a chemical oxygen demand (COD) of 1.0-2.4 $\mathrm{kg} \mathrm{m}^{-3} \mathrm{~d}^{-1}$. After 6 days of operation, the 4-ClA removal efficiency reached $99 \%$ (shown in Fig. 1). The minimum settling velocity of the sludge increased from 1 to $8.1 \mathrm{~m} \mathrm{~h}^{-1}$ after 15 days' operation, and the average sludge diameter was $0.38 \mathrm{~mm}$ and the SVI decreased below $100 \mathrm{~mL} \mathrm{~g}^{-1}$. Since then, the sludge settling time was reduced to $5 \mathrm{~min}$, and the loading of 4-ClA gradually increased to $0.8 \mathrm{~kg} \mathrm{~m}^{-3} \mathrm{~d}^{-1}$. After 65 days of operation, the 4-ClA removal efficiency gradually increased to $99.9 \%$, and the COD removal efficiency remained above $90 \%$ (Fig. 2). With the further increase in the influent 4-ClA loading and sludge concentration in the reactors to $8.53 \mathrm{~g} \mathrm{~L}^{-1}$, the average granular diameter reached 


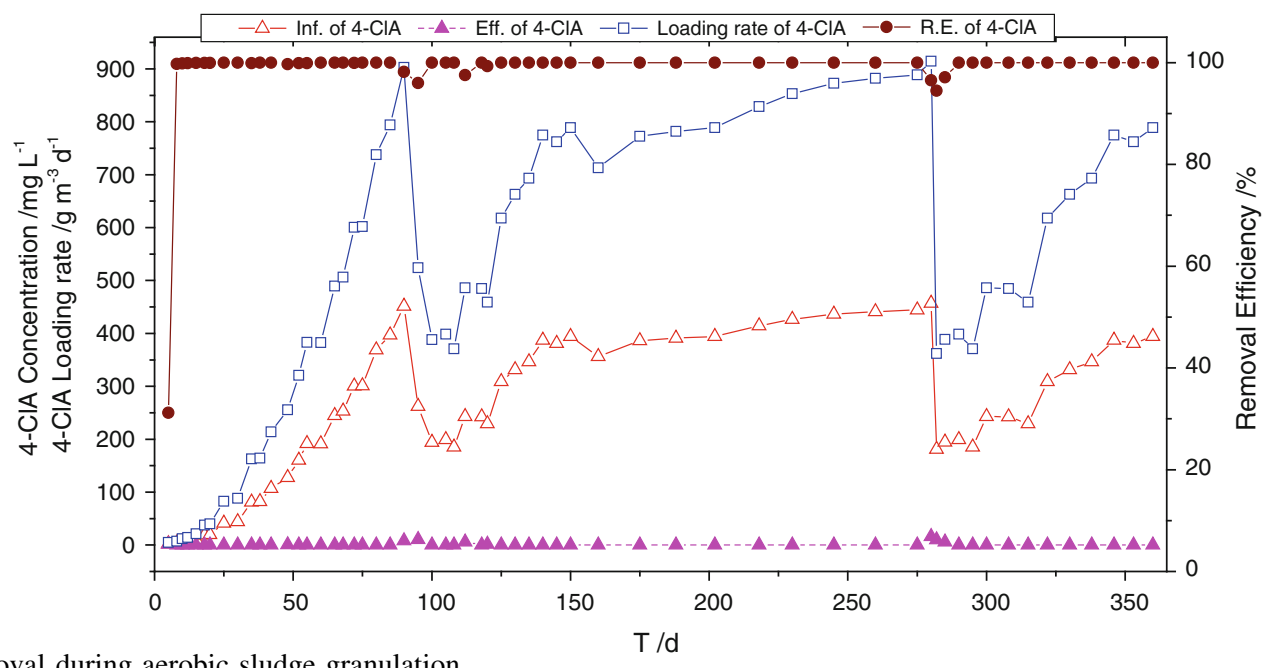

Fig. 1 4-ClA removal during aerobic sludge granulation

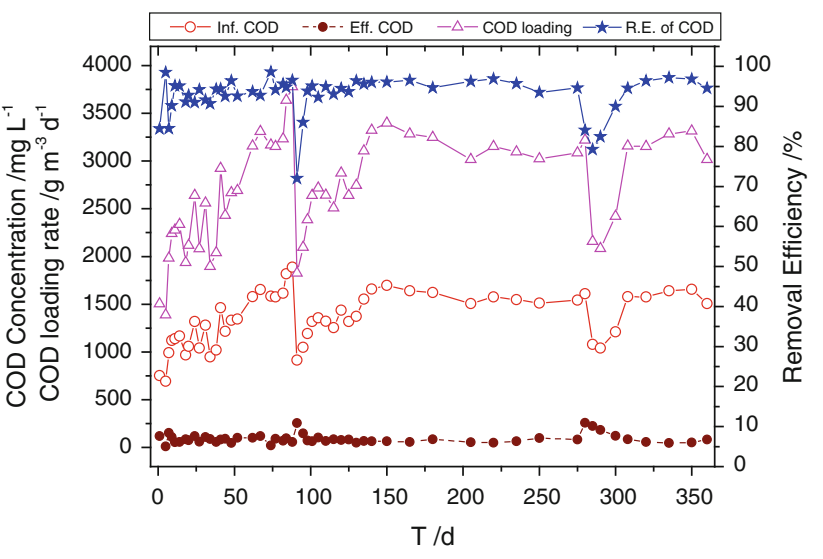

Fig. 2 COD removal during aerobic sludge granulation

$1.19 \mathrm{~mm}$. After 88 days of operation, the influent 4-ClA loading reached $0.9 \mathrm{~kg} \mathrm{~m}^{-3} \mathrm{~d}^{-1}$, and the performance of the reactor deteriorated within 1 week. The sludge SVI increased from 50 to $120 \mathrm{~mL} \mathrm{~g}^{-1}$, and the removal efficiencies of 4-ClA and COD decreased to 98.2 and $77.5 \%$, respectively.

To investigate the recovery and stability of aerobic granular sludge reactor after the instability, influent 4-ClA concentration was reduced to approximately $180 \mathrm{mg} \mathrm{L}^{-1}$. The 4-ClA and COD removal efficiencies recovered within 10 days to above 99 and $90 \%$, respectively, and the reactor operated stably for 5 months under the high 4-ClA loading (119-278 days). After 280 days, the granular reactor became unstable again under high 4-ClA loading approximately $0.9 \mathrm{~kg} \mathrm{~m}^{-3} \mathrm{~d}^{-1}$, and 4-ClA removal efficiency decreased from 99 to $96 \%$. After the adjustment of influent 4-ClA loading and related parameters, the performance of the reactor recovered and stabilized, and the removal efficiencies of 4-ClA, COD, and total nitrogen remained above 99.9, 93, and $70 \%$, respectively. The progress of 4-ClA degradation conformed to Haldane inhibition kinetics with the Haldane equation fitting analysis. The degradation rate increased with the initial concentration and speeded up and declined due to the inhibition of pollutants under high concentration with the kinetic parameters of a $41.72 \mathrm{mg} \mathrm{g} \mathrm{VSS}^{-1} \mathrm{~h}^{-1} \mathrm{Vmax}$, a $267.32 \mathrm{mg} \mathrm{L}^{-1}$ $\mathrm{Ks}$, and a $787.34 \mathrm{mg} \mathrm{L}^{-1} \mathrm{Ki}$.

Microbial community change during the aerobic sludge granulation

Based on the above operational condition and performance of the reactor, sludge samples were obtained from several specific stages for the microbial community analysis, including the start-up period, stable period, and instability period. The PCR-DGGE results are shown in Fig. 3. Thereinto, lanes 1-6 are sludge samples from 0 , $10,25,95,280$, and 360 days, respectively. The similarity and cluster analysis of the DGGE profile are shown in Fig. 3.

Results showed that the microbial community of sludge at different stages maintained relatively abundance, with approximately $16-23$ bands per lane (shown in Fig. 3). However, the community structure changed significantly. During the start-up of the reactor, most of the original bands from inoculated sludge disappeared, and new bands appeared. The changes in band profiles were associated with community succession during sludge granulation and performance recovery. After 10 days of reactor operation, the morphology and color of the sludge changes obviously, and its community 
similarity to the inoculated sludge was $34.8 \%$. During the sludge granulation, disintegration, and recovery, the microbial community succession of sludge was significant, with less than $32.4 \%$ similarity, indicating that the change in sludge morphology correlated with the community structure. Compared with the two instability periods of the reactors (lanes 4 and 5 in Fig. 3), the similarity of sludge microbial structure reached $64.6 \%$, suggesting that the bands that disappeared together may be associated with the dominant microorganism.

For the dominant microorganism analysis of different sludge samples, bands 1-13 from the gel (Fig. 3) were recovered, cloned, and sequenced. The sequences of clones approximately $190 \mathrm{bp}$ in length were compared with those in GenBank using the BLAST program, and the highest

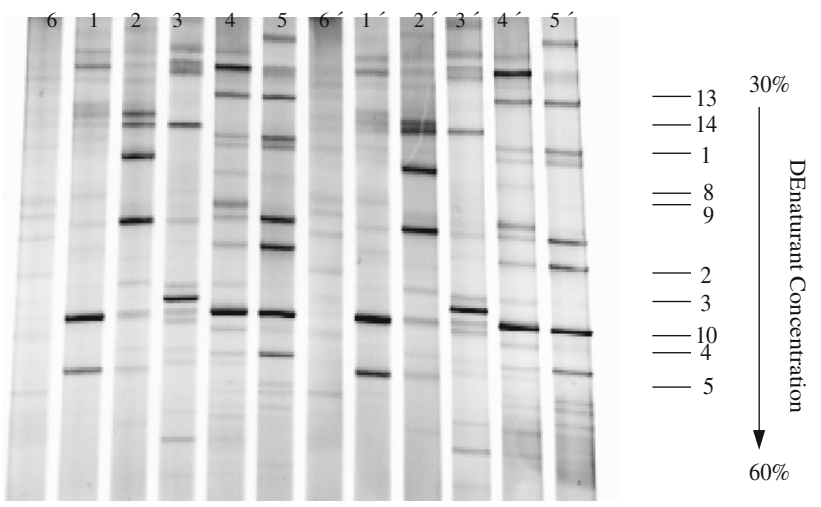

Fig. 3 DGGE profiles of 16S rRNA fragments obtained from aerobic granules $\left(1,1^{\prime}: 0\right.$ days; $2,2^{\prime}: 10$ days; $3,3^{\prime}: 25$ days; $4,4^{\prime}: 95$ days; $5,5^{\prime}: 280$ days; $6,6^{\prime}: 360$ days) sequence similarity analyses are listed in Table 4 . In the bioreactor using 4-ClA as the target pollutant, the stable aerobic granules were dominated with $\beta$-Proteobacteria, Flavobacteriales, Planctomycetales, Clostridiales, and Acidobacteria. The diverse microbial composition of the sludge at different stages may be associated with the influent composition and operational conditions of the reactor.

Structure and function of microflora in microbial aggregates, especially aerobic granules, affect sludge morphology and performance (Boon et al. 2003; Liu et al. 2006). Intensive study on the diverse microbial colonies and high retention of functional microorganisms of aerobic granules, and molecular biology techniques are used for analyzing the relationship between the structure and function of microflora and the stability of biological wastewater treatment systems, which can provide the optimization of process operating conditions and the improvement of system performance (Seviour et al. 2009). Sludge samples were obtained from several specific stages, including the start-up, stable, deterioration, and recovery periods, and the microflora changes in aerobic granular sludge reactor were investigated. According to the results of experiment, the microbial population diversity was relatively rich during the sludge granulation, and the succession of microbial community in the reactor was also significant with the influent 4-ClA concentration, removal efficiency, and sludge morphology. According to the 16S rRNA sequencing results of representative bands, stable aerobic granules degrading high-level 4-ClA were dominated with $\beta$-Proteobacteria $(61.28 \%)$, Flavobacteriales, Planctomycetales, Clostridiales, and Acidobacteria in the bioreactor. The constructed cometabolic
Table 4 Sequences of relevant DGGE fragments from aerobic granules

\begin{tabular}{llrl}
\hline Band & Database match with accession no. in parentheses & $\begin{array}{l}\text { Similarity } \\
(\%)\end{array}$ & $\begin{array}{l}\text { Phylogenetic } \\
\text { group }\end{array}$ \\
\hline 1 & Thauera sp. A17 (AY570693) & 100 & $\beta$-Proteobacteria \\
2 & Thauera sp. B4P (AJ315678) & 99 & $\beta$-Proteobacteria \\
3 & Azoarcus sp. mXyN1 (X83533) & 99 & $\beta$-Proteobacteria \\
4 & Bacterium CYCU-0216 (DQ232380) & 100 & Unknown \\
5 & Uncultured Cytophagales OPB56 (AJ630296) & 91 & Cytophagales \\
6 & Uncultured planctomycete clone T-RF20-23 (AY555682) & 90 & Planctomycetales \\
7 & Uncultured planctomycete clone LiUU-9-3 (AY509495) & 93 & Planctomycetales \\
8 & Thauera sp. DNT-1 (AB066262) & 99 & $\beta$-Proteobacteria \\
9 & Thauera selenatis (Y17591) & 100 & $\beta$-Proteobacteria \\
10 & Uncultured Flavobacteriales bacterium clone LiUU-3-107 & 98 & Flavobacteriales \\
& (AY509268) & & Clostridiales \\
11 & Anoxynatronum sibiricum (AF522323) & 89 & $\gamma$-Proteobacteria \\
12 & Xanthomonas sp. PG-07 (AY56658) & 99 & Acidobacteria \\
& Uncultured Acidobacterium group bacterium clone SBR1013 & 91 & \\
\hline
\end{tabular}




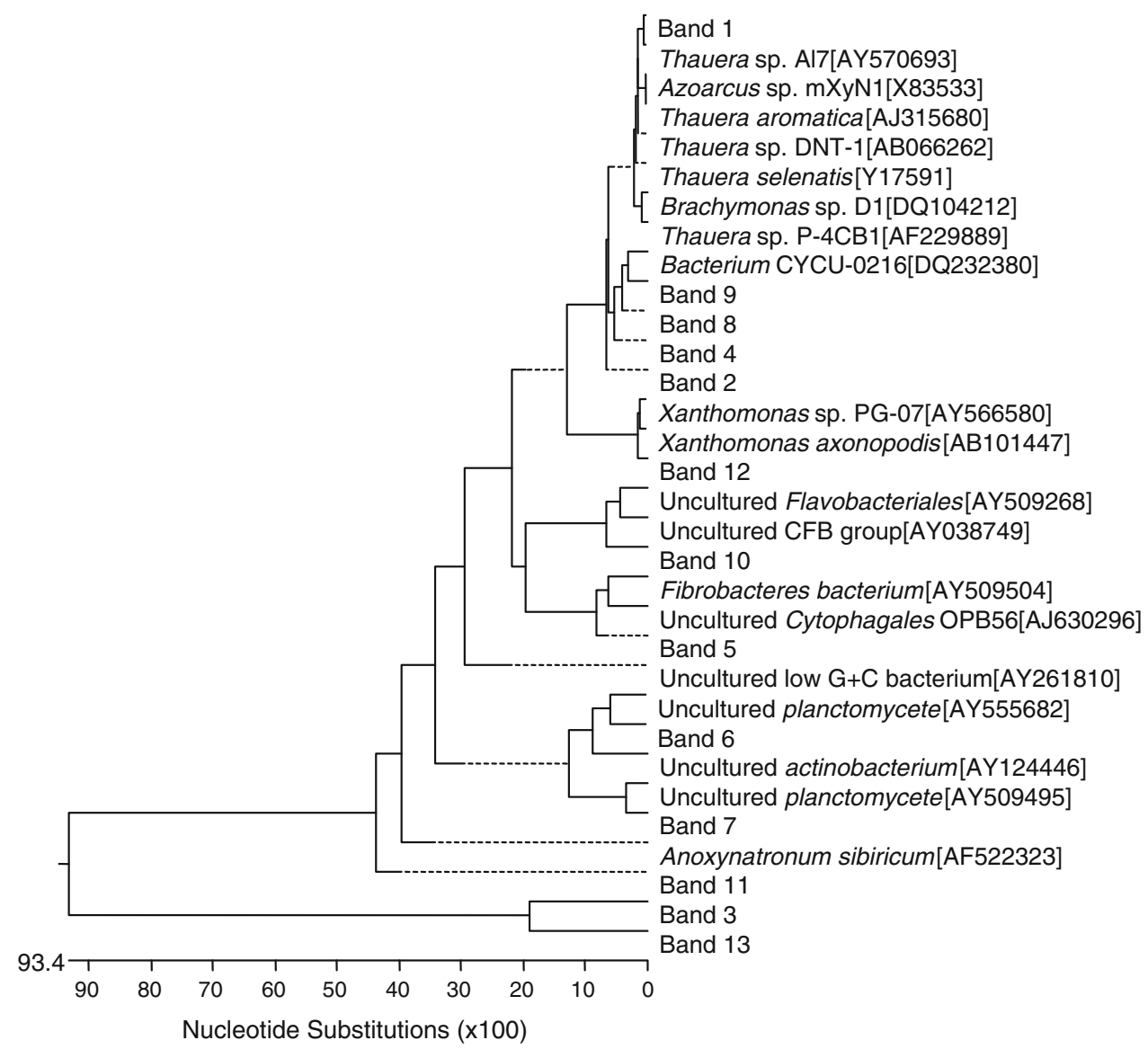

Fig. 4 Phylogenetic tree showing the affiliation-dominant bacteria from aerobic granules for degrading 4-ClA. "Band" refers to the DGGE bands in the polyacrylamide gels. Numbers in parentheses represent the sequences' accession number in GenBank. The number at each branch point is the percentage supported by bootstrap. Bar, $5 \%$ sequence divergence

the uncultured Planctomycete Clone LiUU-9-3 was $93.1 \%$, and the homology between band 10 and the uncultured Flavobacteriales bacterium clone LiUU-3-107 was $96.4 \%$. The sequences of band 3 and band 13 did not match any sequences with greater than $70 \%$ similarity in NCBI GenBank. According to the recommendation by the International Taxonomy Committee, the species boundary is $70 \%$ DNA similarity. Because the above bands 5, 6, 7, and 10 with matched homologies were not found, further studies are needed to verify whether they are indeed new species (Fig. 5).

Quantification of functional microorganism in aerobic 4-ClA-degrading granule

Results of RT-qPCR quantitation of 4-ClA-degrading granule are shown in Table 5. With the operation of the reactor, the proportion of $\beta$-Proteobacteria, Thauera (related to the genus $\beta$-Proteobacteria), and $\mathrm{AOB}$ increased with different degrees. The percentages of AOB 
among total bacteria were maintained at 5.02-10.79\%. The percentages of $\beta$-Proteobacteria among total bacteria were $23.69,46.65,51.22$, and $61.28 \%$ during aerobic sludge granulation. Thereinto, Thauera was barely detectable in inoculated sludge, whereas by 48 days of operation of the reactor and influent 4-ClA loading of $0.16 \mathrm{~kg} \mathrm{~m}^{-3} \mathrm{~d}^{-1}$, Thauera in granular sludge accounted for $9.12 \%$ of total bacteria. After 100 days of operation and the influent 4-ClA loading of $0.8 \mathrm{~kg} \mathrm{~m}^{-3} \mathrm{~d}^{-1}$, the proportion of Thauera in sludge reached $18.34 \%$ of total bacteria. After 120 days of reactor operation, Thauera accounted for more than $20 \%$ of the total bacteria in the stable granular sludge. Results showed that $\beta$-Proteobacteria, especially Thauera, may highly be enriched along with aerobic sludge granulation.

Thauera sp. is a large class of denitrifying microorganism, and studies in recent years have confirmed that these species can degrade aromatic compounds under aerobic and anaerobic conditions (Yang et al. 2011). For example, Thauera sp. DNT-1 can use toluene as its only carbon source in the presence of nitrate, and Thauera sp. P-4CB1 can degrade 4-chlorobenzoate (Shinoda et al. 2004). Liu et al. (2006) found that the percentage of the clones affiliated with the genera Thauera and Azoarcus was $74 \%$ in the denitrifying reactor and $4 \%$ in the

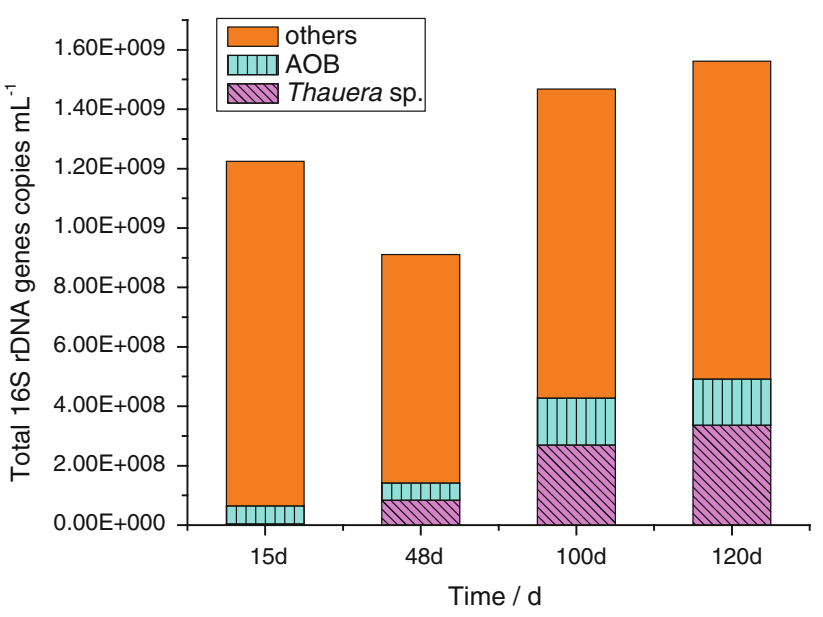

Fig. 5 Abundance of Thauera sp., AOB, and other bacteria in aerobic granules seeding sludge, and the greater abundance of Thauera in association with higher efficiency after adaptation suggested that these phylotypes might play an important role in quinoline and COD removal under denitrifying conditions. The abundance of potential denitrifiers in fullscale wastewater treatment plants suggested that the most abundant potential denitrifiers were related to the genera Aquaspirillum, Azoarcus and Thauera, all within the $\beta$ Proteobacteria. Thereinto, Thauera is the most versatile consuming some volatile fatty acids, ethanol, and amino acids. The coexistence of Aquaspirillum-, Azoarcus-, and Thauera-related bacteria in a range of treatment plants with differences in wastewater, design, and operation suggests that the populations ensure a functional stability of the plants by occupying different ecological niches related to the carbon transformation. Furthermore, a wide variety of bacterial species in full-scale wastewater treatment plants were found at the genera and class level, and some potential degraders such as Thauera were abundant in all samples, which potentially contributed to the strong catabolic activity observed in Biolog assay (Yang et al. 2011). Liu et al. (2006) found that Thauera spp. were important for the formation of acetate-fed granules, accounting for $49 \%$ of the total clones. de Sanctis et al. (2010) also observed that Thauera were enriched during operation of a granular process. Interestingly, Thauera spp. is also found in activated sludges and produces exopolysaccharides which consists predominantly of $N$-acetyl- $\alpha$-fucosamine, $N$-acetyl- $\alpha$-glucosamine, $\beta$-rhamnose, and $\beta$-galacturonic acid. And the highest amount of eDNA was found in and around the microcolonies of denitrifiers belonging to the genera Thauera and Curvibacter, the ammonium-oxidizing Nitrosomonas, and the nitrite-oxidizing Nitrospira, and eDNA was an important structural component in activated sludge biofilms (Dominiak et al. 2011). As also shown in many researches of extracellular polymeric substances (EPS), the highly variable content of EPS, such as protein, polysaccharide, and eDNA, in different bacterial species means that the microbial composition in wastewater treatment plants must affect the properties of microbial aggregates, and thus also drainage and dewatering.
Table 5 16S rRNA gene copies of functional microorganism in aerobic granules

\begin{tabular}{|c|c|c|c|c|}
\hline \multirow[t]{2}{*}{ Stage (days) } & \multicolumn{4}{|c|}{ 16S rRNA gene copies (copies $\mathrm{mL}^{-1}$ ) } \\
\hline & Thauera sp. & $\mathrm{AOB}$ & $\beta$-Proteobacteria & Eubacterium \\
\hline 15 & $3.78 \times 10^{6}$ & $6.12 \times 10^{7}$ & $2.89 \times 10^{8}$ & $1.22 \times 10^{9}$ \\
\hline 48 & $8.31 \times 10^{7}$ & $5.91 \times 10^{7}$ & $4.25 \times 10^{8}$ & $9.11 \times 10^{8}$ \\
\hline 100 & $2.69 \times 10^{8}$ & $1.59 \times 10^{8}$ & $7.53 \times 10^{8}$ & $1.47 \times 10^{9}$ \\
\hline 120 & $3.36 \times 10^{8}$ & $1.56 \times 10^{8}$ & $9.56 \times 10^{8}$ & $1.56 \times 10^{9}$ \\
\hline
\end{tabular}




\section{Conclusion}

Results showed that the $\beta$-Proteobacteria class dominated the aerobic granular sludge and some important functional groups such as Thauera related to the performance of wastewater treatment were relatively abundant. Complex microbial community plays a key role in the aerobic sludge granulation, and a thorough knowledge of microbial information about the microbial composition and their EPS production is essential to develop the operating strategies and improve process performance of aerobic granule in the future.

Acknowledgments This work was funded by the National Natural Science Foundation of China (Nos. 51078327 and 51008269) and Zhejiang Environmental Protection R\&D Project (No. 2011B10).

\section{References}

Adav SS, Lee DJ, Show KY, Tay JH (2008) Aerobic granular sludge: recent advances. Biotechnol Adv 26(5):411-423

American Public Health Association (APHA) (1998) Standard methods for the examination of water and wastewater. Washington DC

Bathe S, Schwarzenbeck N, Hausner M (2009) Bio augmentation of activated sludge towards 3-chloroaniline removal with a mixed bacterial population carrying a degradative plasmid. Bioresour Technol 100(12):2902-2909

Beun JJ, van Loosdrecht MCM, Heijnen JJ (2002) Aerobic granulation in a sequencing batch airlift reactor. Water Res $36: 702-712$

Boon N, De Gelder L, Lievens H (2002) Bio augmenting bioreactors for the continuous removal of 3-chloroaniline by a slow release approach. Environ Sci Technol 36(21):4698-4704

Boon N, Top EM, Verstraete W, Siciliano SD (2003) Bio augmentation as a tool to protect the structure and function of an activated-sludge microbial community against a 3-chloroaniline shock load. Appl Environ Microbiol 69:1511-1520

Chen Y, Jiang W, Liang DT, Tay JH (2007) Structure and stability of aerobic granules cultivated under different shear force in sequencing batch reactors. Appl Microbiol Biotechnol 76(5): 1199-1208

de Kreuk MK, Kishida N, Tsuneda S, van Loosdrecht MCM (2010) Behavior of polymeric substrates in an aerobic granular sludge system. Water Res 44(20):5929-5938

de Sanctis M, Di Iaconi C, Lopez A, Rossetti S (2010) Granular biomass structure and population dynamics in sequencing batch biofilter granular reactor (SBBGR). Bioresour Technol 101: 2152-2158

Deng YQ, Zhang Y, Gao YX, Li D, Liu RY, Liu MM, Zhang HF, Hu B, Yu T, Yang M (2012) Microbial community compositional analysis for series reactors treating high level antibiotic wastewater. Environ Sci Technol 46(2):795-801

Dominiak DM, Nielsen JL, Nielsen PH (2011) Extracellular DNA is abundant and important for microcolony strength in mixed microbial biofilms. Environ Microbiol 13(3):710-721

Gao DW, Liu L, Liang H, Wu WM (2011) Aerobic granular sludge: characterization, mechanism of granulation and application to wastewater treatment. Crit Rev Biotechnol 31(2):137-152
Grabowski A, Nercessian O, Fayolle F, Blanchet D, Jeanthon C (2005) Microbial diversity in production waters of a lowtemperature biodegraded oil reservoir. Fems Micriobiol Ecol 54(3):427-443

Jiang HL, Tay JH, Maszenan AM, Tay STL (2004) Bacterial diversity and function of aerobic granules engineered in a sequencing batch reactor for phenol degradation. Appl Environ Microbiol 70(11):6767-6775

Liu YQ, Tay JH (2008) Influence of starvation time on formation and stability of aerobic granules in sequencing batch reactors. Bioresour Technol 99:980-985

Liu BB, Zhang F, Feng XX, Liu YD, Yan X, Zhang XJ, Wang LH, Zhao LP (2006) Thauera and Azoarcus as functionally important genera in a denitrifying quinoline-removal bioreactor as revealed by microbial community structure comparison. FEMS Mivrobiol Eco 55(2):274-286

Malik A, Sakamoto M, Hanazaki S, Osawa M, Suzuki T, Tochigi M, Kakii K (2003) Coaggregation among nonflocculating bacteria isolated from activated Sludge. Appl Environ Microbiol 69:6056-6063

Morgenroth E, Sherden T, van Loosdrecht MCM, Heijnen JJ, Wilderer PA (1997) Aerobic granular sludge in a sequencing batch reactor. Water Res 31:3191-3194

Muyzer G, Dewaal E, Uitterlinden AG (1993) Profiling of complex microbial population by denature gradient gel electrophoresis analysis of polymerase chain reaction-amplified genes coding for 16S rDNA. Appl Environ Microbial 59:695-700

Ni BJ, Yu HQ (2010) Mathematical modeling of aerobic granular sludge: a review. Biotechnol Adv 28(6):895-909

Scholten E, Lukow T, Auling G, Rainey FA, Diekmann H, Lukow T (1999) Thauera mechernichensis sp. nov., an aerobic denitrifier from a leachate treatment plant. Int J Syst Bacteriol 49:1045-1051

Seviour T, Pijuan M, Nicholson T, Keller J, Yuan ZG (2009) Understanding the properties of aerobic sludge granules as hydrogels. Biotechnol Bioeng 102(5):1483-1493

Shinoda Y, Sakai Y, Uenishi H, Uchihashi Y, Hiraishi A, Yukawa H, Yurimoto H, Kato N (2004) Aerobic and anaerobic toluene degradation by a newly isolated denitrifying bacterium, Thauera sp. strain DNT-1. Appl Environ Microbiol 70:1385-1392

Song B, Kerkhof LJ, Haggblom MM (2002) Characterization of bacterial consortia capable of degrading 4-chlorobenzoate and 4-bromobenzoate under denitrifying conditions. FEMS Microbiol Lett 213:183-188

Uan DK, Yeom IT, Arulazhagan P, Rajesh Banu J (2013) Effects of sludge pretreatment on sludge reduction in a lab-scale anaerobic/ anoxic/oxic system treating domestic wastewater. Int J Environ Sci Tech 10(3):495-502

Wan JF, Bessiere Y, Sperandio M (2009) Alternating anoxic feast/ aerobic famine condition for improving granular sludge formation in sequencing batch airlift reactor at reduced aeration rate. Water Res 43(20):5097-5108

Winkler MKH, Bassin JP, Kleerebezem R, de Bruin LMM, Van Den Brand TPH, Van Loosdrecht MCM (2011) Selective sludge removal in a segregated aerobic granular biomass system as a strategy to control PAO-GAO competition at high temperatures. Water Res 45(11):3291-3299

Yang C, Zhang W, Liu RH, Li Q, Li BB, Wang SF, Song CJ, Qiao CL, Mulchandani A (2011) Phylogenetic diversity and metabolic potential of activated sludge microbial communities in full-scale wastewater treatment plants. Environ Sci Technol 45(17):7408-7415

Zhang S, Li A, Cui D, Yang J, Ma F (2011) Performance of enhanced biological SBR process for aniline treatment by mycelial pellet as biomass carrier. Bioresour Technol 102(6): $4360-4365$ 
Zhu L, Xu XY, Luo WG, Tian ZJ, Lin HZ, Zhang NN (2008) A comparative study on the formation and characterization of aerobic 4-chloroaniline-degrading granules in SBR and SABR. Appl Microbial Biotechnol 79(5):867-874
Zhu L, Yu YW, Xu XY, Tian ZJ, Luo WG (2011) High-rate biodegradation and metabolic pathways of 4-chloroaniline by aerobic granules. Process Biochem 46:894-899 